\title{
The Impact of Emotional Processes on Stuttering in Young School-Age Children Who Do and Do Not Stutter
}

\author{
Haewon Kim ${ }^{\text {a }}$, Dahye Choi ${ }^{\text {, }}$ Hyun Sub Sim ${ }^{\text {a }}$ \\ ${ }^{a}$ Department of Communication Disorders, Graduate School, Ewha Womans University, Seoul, Korea \\ ${ }^{b}$ Department of Speech Pathology and Audiology, University of South Alabama, Mobile, Alabama, USA
}

Correspondence: Hyun Sub Sim, PhD Department of Communication Disorders, Ewha Womans University, 52 Ewhayeodae-gil, Seodamun-gu, Seoul 03760, Korea

Tel: $+82-2-3277-3538$

Fax: $+82-2-3277-2122$

E-mail: simhs@ewha.ac.kr

Received: January 4, 2021

Revised: February 6, 2021

Accepted: February 17, 2021
Objectives: The purpose of this study was to investigate the differences in emotional processes (emotional reactivity and emotional regulation) between children who stutter (CWS) and children who do not stutter (CWNS). In addition, we attempted to explore whether positive or negative emotion-eliciting conditions increase stuttering in CWS and CWNS. Methods: Twelve young school-age CWS and thirteen young school-age CWNS participated in this research. The Korean version of the Children's Behavior Questionnaire Short Form (CBQ-SF) was employed to investigate the characteristics of children's emotional processes (i.e., three factors: Surgency, Negative Affectivity, \& Effortful control). Each participant completed a series of tasks that were designed to elicit emotions such as neutral, anxiety, pleasure, and frustration. After each task, the participant was asked to tell a story based on a wordless picture book. Results: Findings indicated (1) no significant differences in the three factors of emotional processes between CWS and CWNS; (2) no significant correlations between the three factors of emotional processes and speech disfluency rates (i.e., other disfluencies, OD and stuttering-like disfluencies, SLD) in CWS and CWNS; and (3) a significant difference in SLD between the frustration and neutral conditions for CWS but not for CWNS. Conclusion: The findings from this study suggest that although CWS are not necessarily different from CWNS in emotional reactivity and regulation, CWS's speech system seems to be vulnerable to a frustrating situation and their speech fluency is more likely to be disrupted by the frustrating emotion.

Keywords: Young school-age children, Stuttering, Emotional processes, Emotional stressor, Disfluency
Developmental stuttering occurs in $1 \%$ of the general population and 1\% of school-age children (Bloodstein, 1995; Bloodstein \& Bernstein-Ratner, 2008). Although our knowledge about stuttering has significantly increased over the past decades, the causes of the onset and development of stuttering remain unclear. Previous research has shown that stuttering results from a combination of multiple factors such as linguistic, genetic, motor, and emotional factors (Smith \& Weber, 2017). Among these factors, increased attention has been paid recently to the relationship between emo- tion and stuttering, specifically focusing on emotional processes. Emotional processes consist of emotional reactivity and emotional regulation. Emotional reactivity refers to the propensity of a person to experience constant and strong emotional arousal. It is divided into positive and negative emotional reactivity, thus negative and positive emotions are important elements of emotional reactivity (Spinrad et al., 2004). Similarly, emotional regulation refers to the process of monitoring, regulating and sustaining emotions during emotional arousal (Thompson, 1994). Emotional regula- 
tion can be defined as the concept of regulating the emotional response of negative or positive emotions (Ahadi \& Rothbart, 1994). Some researchers have claimed that stuttering causes emotional processes, while others have claimed that emotional processes cause stuttering. Although it seems obvious that stuttering and emotional processes interact with each other, the exact mechanism underlying the relationship appears still be elusive because it is difficult to examine the two opposite paths separately (Conture, Kelly, \& Walden, 2013). To determine the role emotion plays in the onset and development of stuttering, researchers have used the following two methodologies. First, some researchers have investigated the relationship between temperament and stuttering in the hope that the findings would shed light on the direction of the relationship between emotion and stuttering (e.g., Choi, Conture, Walden, Lambert, \& Tumanova, 2013; Conture et al., 2006; Johnson, Walden, Conture, \& Karrass, 2010; Ntourou et al., 2013). Temperament is known to be observed from infancy, making its occurrence precede stuttering in timing. Thus, the presumption has been that if there is an association between temperament and stuttering, it may suggest that emotional processes contribute to stuttering (e.g., Anderson, Pellowski, Conture, \& Kelly, 2003). Second, others have carefully designed experiments to manipulate emotional stimuli and measure the stuttering that results from the manipulation (e.g., Johnson et al., 2010; Ntourou et al., 2013; Walden et al., 2012).

Three main analysis methods are used to measure emotional processes of children who stutter (CWS). There are methods of parent-report questionnaires by caregiver, behavioral observations by directly observing and analyzing the child's behavior, and psychophysiology by using electroencephalographic, respiratory sinus arrhythmia. In the measurement of parent-reports, the Behavioral Style Questionnaire (BSQ; McDevitt \& Carey, 1978) and Child Behavior Questionnaire (CBQ; Rothbart, Ahadi, Herschey, \& Fischer, 2001) are widely used in research on the emotional processing of children. Recently, the CBQ scale test has been actively used not only abroad but also in Korea (Cha, 2015; Park, 2015). Studies of emotional processes based on parent-reports and behavioral observations have indicated that CWS, when compared to children who do not stutter (CWNS), had (1) greater activity and more reactivity (Anderson et al., 2003; Eggers, de Nil, \& van den Bergh, 2010; Karrass et al., 2006; Schwenk, Conture, \& Walden, 2007), (2) higher anger/frustration and more negative emotions (Eggers et al., 2010; Johnson et al., 2010; Ntourou et al., 2013), (3) lower adaptability (e.g., Anderson et al., 2003; Howell et al., 2004; Schwenk et al., 2007), and (4) lower inhibitory control and poor attention regulation (Eggers et al., 2010; Karrass et al., 2006). Conversely, other researchers reported no significant difference in negative emotions between CWS and CWNS (Cha, 2015; Lewis \& Goldberg, 1997; Park, 2015). When the relationship between emotional processes and disfluencies (other disfluencies [OD] and stuttering-like disfluencies [SLD]) was examined, the findings indicated that CWS had a higher negative emotional reactivity during their disfluent utterances (Jones, Conture, \& Walden, 2014). Conversely, there was no relationship between emotional processes (emotional reactivity, emotional regulation) and disfluencies (OD, SLD) for CWS, but a negative affect was related to OD for CWNS (Ntourou et al., 2013).

On the other hand, Johnson et al. (2010) found that CWS were more disfluent after receiving a desirable gift than after receiving a disappointing gift. Similarly, CWS's positive emotional reactivity significantly correlated with stuttering frequency, while negative emotional reactivity did not (Choi, Conture, Walden, Jones, \& Kim, 2016). In addition, CWS who used less emotional regulation showed increased disfluencies, whereas no such relationship was found for CWNS (Arnold, Conture, Key, \& Walden, 2011; Walden et al., 2012).

According to the Communication Emotional (CE) model of stuttering (Conture et al., 2006), temperamental characteristics such as emotional reactivity and regulation may exacerbate stuttering over time. Also, the Dual Diathesis-Stressor (DD-S) model of stuttering (Conture \& Walden, 2012) suggests that variable emotional stressors may activate relatively stable emotional diathesis (i.e., vulnerability), which, in turn, is associated with disruptions in fluent speech and language planning and/or production. In other words, the effect of emotional processes on stuttering can be insignificant unless the emotional processes are triggered by emotional stressors. Given the DD-S model of stuttering, it can be speculated that the previous studies' null findings may be due to their having employed emotional stimuli that are not strong enough to activate emotional diathesis in CWS. Therefore, in this 
study, we used both emotional processes and emotional stressors to see if the emotional processes characteristics were actually different between CWS and CWNS, and to see if emotions affect stuttering in situations where emotions are actually triggered.

Previous studies used various emotional stressors such as: (1) audio recordings played in the background containing conversations between adult actresses who conveyed angry, happy, and neutral emotions (Arnold, Conture, Key, \& Walden, 2011; Jones et al., 2014); (2) positive, negative, or neutral video clips (Choi et al., 2016); (3) desirable gifts and disappointing gifts to stimulate positive/negative emotions (Johnson et al., 2010); and (4) the "apples and leaves in transparent box" (ALTB) task in a neutral condition and the "attractive toy in a transparent box" (ATTB) in a frustrating condition (Ntourou et al., 2013). In the studies using audio and video recordings like (1) and (2) above, children were passively stimulated by stressors, whereas in the studies that used behavioral testing methods like (3) and (4), children were actively stimulated by stressors. The present study was designed to employ active experimental methods because these methods appear to be more likely to activate emotions than passive methods. Therefore, this study created emotional stressor stimuli based on neurophysiological motivational systems. Emotional processes are motivational systems that are sensitive to rewards and punishments (Rothbart \& Bates, 2006), which can be activated to generate behavior and emotions (Gray, 1987). Based on this motivation system, this study structured a direct play situation with reward and punishment clues. In other words, this study created activities that cause pleasure through a rewarded play situation, frustration through a play situation without a reward, and anxiety through a tense situation. Whereas indirect stimuli were presented to children in previous studies, this study was designed to allow children to feel real emotions in each situation while directly participating in play.

Previous studies included four types of emotional stressor conditions: neutral, anger, pleasure, and frustration. However, in this study, the anger condition was excluded because it was considered ethically unsuitable to elicit an anger reaction from a child in a behavioral manner and because the researchers believed that it was more appropriate to give the frustration condition, which is the same pattern as anger, as a negative emotion. Also, the anxiety condition was added because some recent studies reported that stuttering children tend to have a significant relationship between anxiety and stuttering (e.g., Alm, 2014; Iverach, Menzies, O’Brian, Packman, \& Onslow, 2011; Kefalianos, Onslow, Block, Menzies, \& Reilly, 2012). Therefore, this study was designed to assess children's performance of a task under four emotional conditions: neutral, anxiety, pleasure, and frustration. In addition, this study focused on school-age stuttering children. School-age CWS who experience stuttering for a longer period of time than pre-school age CWS may be more likely to be exposed to negative reactions to stuttering and develop more negative emotions toward stuttering compared to preschool-age CWS.

Therefore, the purpose of the study was to investigate the differences in emotional reactivity and emotion regulation between school-age CWS and CWNS. In addition, we attempted to explore whether children's emotional processes are associated with their speech disfluency. Lastly, we examined speech disfluencies under the four emotion-inducing conditions described above. For the purpose of the study, the following research questions were addressed:

1. Do school-age CWS and CWNS significantly differ in emotional processes (emotional reactivity and regulation)?

2. Are there relationships between emotional processes and speech disfluencies (other disfluencies, OD and stutteringlike disfluencies, SLD) within each group (CWS, CWNS)?

3. Do CWS and CWNS produce more speech disfluencies during emotion-inducing conditions (anxiety, pleasure, and frustration) compared to the neutral condition?

\section{METHODS}

\section{Participants}

Participants were 12 school-age CWS (12 boys) and 13 age-matched school-age CWNS ( 9 boys and 4 girls), all of whom were monolingual, native speakers of Korean. Participants were between the ages of 6;0 [years; months] and 8;11 (CWS: $M=91.33$ months, $\mathrm{SD}=11.73$; CWNS: $\mathrm{M}=97.15$ months, $\mathrm{SD}=7.17$ ). They were recruited through regionally distributed parent-oriented online site, self/professional referral to Ewha Woman University Speech-Language Laboratory, and a private speech-language clinic.

CWS were 1) reported as stuttering by parents and speech-lan- 
guage pathologists, 2) they were diagnosed as having a fluency disorder classified as "mild" or more by the Paradise-Fluency Assessment-II (P-FA-II; Sim, Shin, \& Lee, 2010). In this assessment, five CWS obtained the severity of stuttering between 1 to 40 percentiles as 'mild', four CWS obtained 41 to 80 percentile severity as 'moderate', and three CWS obtained above 81 percentile severity as 'severe', 3) they reported by parents and speech-language pathologists that they did not have developmental, emotional, sensory, or articulation disorders, and they had normal intelligence, 4) They also received -1 SD or higher on receptive and expressive language development according to the Receptive and Expressive Vocabulary Test (REVT; Kim, Hong, Kim, Jang, \& Lee, 2009), and 5) Eight children were receiving treatment for less than six months, and four children were receiving treatment for more than a year. And they were not receiving direct treatment for anxiety or emotional disorders and did not have other accompanying disorders.

On the other hand, CWNS were 1) reported as not stuttering by their parents, family, class teacher or speech-language pathologists, 2) they reported by parents and speech-language pathologists that they did not have developmental, emotional, sensory, or articulation disorders, and they had normal intelligence, 3) they also received -1 SD or higher on receptive and expressive language development on the REVT, 4) they were also not receiving direct treatment for anxiety or emotional disorders and did not have other accompanying disorders.

There was no significant difference in chronological age $\left(F_{(1,23)}=2.280, p=.145\right)$, receptive vocabulary scores $\left(F_{(1,23)}=.290\right.$, $p=.595)$, and expressive vocabulary scores $\left(F_{(1,23)}=.061, p=.807\right)$ between CWS and CWNS (Table 1). The background information of the two groups was presented in Appendixl and 2.

Table 1. Participants' age and vocabulary

\begin{tabular}{lccc}
\hline & CWS $(\mathrm{n}=12)$ & CWNS $(\mathrm{n}=13)$ & $p$ \\
\hline Age (in months) & $91.33(11.73)$ & $97.15(7.17)$ & .145 \\
Receptive vocabulary $^{\mathrm{a}}$ & $97.33(16.62)$ & $93.92(15.04)$ & .595 \\
Expressive vocabulary $^{\mathrm{a}}$ & $97.41(15.75)$ & $96.23(7.00)$ & .807 \\
\hline
\end{tabular}

Values are presented as mean (standard deviation, SD).

CWS = children who stutter; CWNS = children who do not stutter.

aReceptive \& Expressive Vocabulary Test (Kim, Hong, Kim, Jang, \& Lee, 2009).

\section{Procedure}

The experiment was conducted in a quiet room where the children were not directly disturbed. Before proceeding with the experiment, the researcher gave each child a full explanation of the sequence and tasks of the experiment and asked for video recording consent. The parents and children gave consent for the experiment. A video camera was set up in a room so that the children could remain comfortable with the video recording. Then, the child's caregiver was asked to leave the room and fill out the Children's Behavior Questionnaire in a separate room. In order to measure the rates of disfluencies under the four emotional stressors, the emotional stressor tasks were conducted with the child, followed by the storytelling task to collect the child's spontaneous utterances. After the storytelling task, the child was asked to report how they felt to ensure that the targeted emotion was experienced. Specifically, the sequence of experimental session is: 1) the children previewed the storybook assigned to each of the emotional situations, 2) the emotional stressor tasks were conducted with the child, With the exception of the neutral condition, the order of the emotional stressor task was counterbalanced to avoid ordering effect; the neutral condition was placed prior to and following each of the anxiety, pleasure, and frustration conditions, 3) after each emotional stress condition, the children were instructed to tell the story while viewing the picture book. The storytelling task was carried out with five frog stories in random order.

\section{Measurements}

\section{Children's Behavior Questionnaire Short Form (CBQ-SF)}

Putnam and Rothbart (2006) proposed the CBQ-SF to assess the emotional reactivity and regulation. The CBQ-SF was developed to provide a highly reliable caregiver report assessment of temperament in children 3 to 8 years of age. In this study, we used the Korean version of the CBQ-SF (Cha, 2015) whose validity has been established by Lee (2004) and Lim and Bae (2015). The questionnaire consists of 94 questions that assess three broad factors and 15 scales. The broad factors consist of Surgency (an index of positive emotional reactivity), Negative Affectivity (an index of negative emotional reactivity), and Effortful Control (an index of effortful control). The scales associated with Surgency are Activity 
Level, High-intensive Pleasure, Impulsivity, Shyness, and Approach/ Positive Anticipation. Likewise, the scales associated with Negative Affectivity are Anger/Frustration, Discomfort, Fear, Sadness, and Falling Reactivity/Soothability. In addition, the scales associated with Effortful Control are Attentional Focus, Inhibitory Control, Low-intensity Pleasure, Perceptual Sensitivity, and Smiling/ Laughter. Each question on the CBQ-SF is evaluated on a 7-point Likert scale, and the higher the score, the stronger the characteristics of the factor.

\section{Emotional stressor task}

In this study, the rates of disfluencies (OD and SLD) that the two groups produced after the four emotional stress conditions were measured. The task consisted of four emotional stress conditions (neutral, anxiety, pleasure, and frustration), which were designed to generate neutral, positive (i.e., pleasure), and negative (i.e., anxiety and frustration) emotions. The anxiety, pleasure, and frustration tasks were designed by modifying the presentation and bead sorting game used by Zalewski, Lengua, Wilson, Trancik, and Bazinet (2011), and another experimenter was added for the efficiency of the tasks. The specific experiments used for the emotional stressor tasks were as follows. During the neutral stress condition, children viewed a 4-minute animated fish tank screensaver video. In the anxiety stress condition, the child was given the instruction: "From now on, you will come out here and give a presentation. I will check your facial expressions, postures, and voice while you are talking. We will rate how well you speak. Tell me about the frog story on the microphone." The child stood in front of two experimenters making a presentation, and the experimenters scored the child's presentation with a stern and evaluative look. In the pleasure stress condition, experimenter 1 told the child that they would play a game of marbles, and then experimenter 2 entered the examination room. Experimenter 1 explained the rules of the game to the child and experimenter 2 , and the child played the game with experimenter 2 . A total of three games were played over three minutes, and the situation was structured so that the child could win the game. After the child won, a gift was offered to the child as a reward. In the frustration stress condition, experimenter 1 told the child that they would play a game of marbles, and then experimenter 2 entered the examination room. Experi- menter 1 explained the rules of the game to the child and experimenter 2, and the child played the game with experimenter 2. A total of three games were played over three minutes, and the situation was structured so that the child lost the game. After the game, experimenter 1 offered rewards to experimenter 2, who won the game, and did not give any to the child.

\section{Storytelling task}

Subsequently, after each emotional stress condition, the children produced a narrative while viewing a wordless picture book. For the efficiency of the storytelling task and to reduce the burden by recognizing and preparing the contents of the storybook, before each emotional stress condition was introduced, the children previewed the storybook assigned to each of the emotional situations. After each emotional stress condition, the children were instructed to tell the story while viewing the picture book. In this study, five stories were selected from "Frog story" series by the author Mercer Mayer (1967, 1969, 1971, 1974, 1975). These storybooks are frequently used for storytelling tasks in studies. (Choi et al., 2016; Erdemir, Walden, Jefferson, Choi, \& Jones, 2018).

\section{Manipulation check}

After each storytelling task, a simple manipulation check was conducted to assess whether the target emotions were induced in the children during emotional stressor tasks. First, the child was asked to choose one of the five facial expressions presented in a picture (i.e., pleasure, anger, anxiety, frustration, and neutral) that corresponded to their emotion. Next, the child was asked to rate the degree of emotion on a 3-point scale (i.e., one meaning "a little", two meaning "some", and three meaning "a lot").

CWS and CWNS chose appropriate facial expressions that represented the targeted emotions. All 12 CWS (100\%) chose the targeted emotion for the pleasure task, 10 CWS (83.33\%) did for the anxiety task, and 10 CWS (83.33\%) did for the frustration task. Similarly, all 13 CWNS (100\%) chose the targeted emotion for the pleasure task, 10 CWNS (76.92\%) did for the anxiety task, and 11 CWNS (84.62\%) did for the frustration task. The degrees of emotion for each task were as follows: for CWS, pleasure task $(M=2.75$, $\mathrm{SD}=0.45)$, anxiety task $(\mathrm{M}=1.33, \mathrm{SD}=0.49)$, and frustration task $(M=1.92, S D=0.79)$, and for CWNS, pleasure task $(M=2.54$, 
$\mathrm{SD}=0.78)$, anxiety task $(\mathrm{M}=1.77, \mathrm{SD}=0.73)$, and frustration task $(\mathrm{M}=1.69, \mathrm{SD}=0.95)$. These results show that although there were slight differences in the degree of emotion experienced by both groups, most children experienced the intended emotion for each task.

\section{Data Analysis}

CBQ-SF

As stated previously, a total of 94 questions are included in the CBQ-SF, which measures Surgency, Negative Affectivity, and Effortful Control. The Surgency score was calculated by averaging the scores for Approach, High- Intensive Pleasure, Activity Level, Impulsivity, and Shyness. The Negative Affectivity score was calculated by averaging the scores for Discomfort, Fear, Anger/Frustration, Sadness, and Falling Reactivity/Soothability. Similarly, the Effortful Control score was calculated by averaging the scores for Inhibitory Control, Attentional Focused, Low-intensity Pleasure, Perceptual Sensitivity, and Smiling/Laughter.

\section{Types and rates of disfluency}

According to the speech disfluency classification of Ambrose and Yairi (1999), this study divided speech disfluencies into OD and SLD. OD includes four subtypes: interjections, revisions, multisyllable repetitions, and phrase repetitions, and SLD includes five subtypes: single-syllable repetitions, part-word repetitions, prolongations, blocks, and broken words. Each child was encouraged to produce more than 200 syllables. All speech samples (ranged from 211 to 817 syllables) were collected and analyzed for data analysis. $86 \%$ of all the children produced more than 300 syllables. On average, CWS uttered 359.45 syllables and CWNS uttered 498.42 syllables. The percentage of OD and SLD of each child was calculated by dividing the number of syllables of OD and SLD respectively by the total number of syllables produced by each child and multiplying the results by 100 .

\section{Reliability and Statistical Analysis \\ Measurement reliability}

To assess inter-judge reliability, $20 \%$ of the total data were randomly selected, and OD and SLD were recoded and recounted by a second coder who is a second-degree speech-language pathologist with more than a year of experience in stuttering assessment and treatment. The second coder was blind to all participants and coded speech samples independently to access reliability. The number of agreements between the first author and the second coder for the frequency of the disfluencies (OD, SLD) was divided by the total frequency of disfluencies and multiplied by 100 to obtain the percentage of inter-judge reliability with the speech samples.

In OD, inter-judge agreement for the neutral task was $91.67 \%$ for CWS and 93.75\% for CWNS. Agreement for the anxiety task was $92.5 \%$ for CWS and $92.98 \%$ for CWNS. Agreement for the pleasure task was $90.38 \%$ for CWS and $91.11 \%$ for CWNS, and agreement for the frustration task was $93.93 \%$ for CWS and $90.48 \%$ for CWNS. In SLD, inter-judge agreement for the neutral task was 92.72\% for CWS and 90.91\% for CWNS. Agreement for the anxiety task was $92.94 \%$ for CWS and $94.73 \%$ for CWNS. Agreement for the pleasure task was $93.34 \%$ for CWS and $94.12 \%$ for CWNS, and agreement for the frustration task was $91.03 \%$ for CWS and $92.86 \%$ for CWNS.

\section{Statistical analysis}

First, two-independent samples t tests were performed to examine whether there was a difference in emotional reactivity and regulation between the school-age CWS and CWNS. Second, Spearman correlations were performed to assess the relationship between emotional reactivity and regulation and the rates of OD and SLD within school-age CWS and CWNS. In this statistical analysis, a Bonferroni adjustment $(\alpha=.025)$ was applied to control for a possible Type I error (i.e., false-positive findings). Third, a two-way mixed ANOVA was performed to determine whether there were differences in the rates of speech disfluencies among the four emotional stress conditions and whether there was any interaction effect between the talker group (i.e., CWS vs. CWNS) and emotional stressor conditions in impact speech disfluencies. In this statistical analysis, for SLD, the degree of freedom was adjusted to Greenhouse Geisser epsilon because the sphericity assumption was not established. Post-host analysis of the interaction effects was performed with a one-way within-subject ANOVA, and the rest of the post-host analysis was conducted with Bonferroni. 


\section{RESULTS}

\section{Emotional Reactivity and Regulation between CWS and CWNS}

The findings indicated no significant differences in (a) Surgency $\left(t_{(23)}=.340, p=.737\right.$, Cohen's $\left.d=.14\right)$, (b) Negative Affectivity $\left(t_{(23)}=\right.$ $1.636, p=.115$, Cohen's $d=.65)$, and (c) Effortful Control $\left(t_{(23)}=\right.$ $-1.436, p=.164$, Cohen's $d=-.57$ ) scores between CWS and CWNS (Table 2).

\section{Relationship among Emotional Reactivity and Regulation and the Rates of Disfluencies (OD, SLD) within Each Group}

The findings indicated no significant correlation between all emotional processes and the rates of disfluencies: (a) Surgency and $\mathrm{OD}(r=.042, p=.897)$, (b) Surgency and SLD $(r=.074, p=.82)$, (c) Negative Affectivity and OD $(r=-.545, p=.067)$, (d) Negative Affectivity and SLD ( $r=.007, p=.983)$, (e) Effortful Control and OD $(r=-.004, p=.991)$, and (f) Effortful Control and SLD ( $r=.182$, $p=.571)$ within CWS. Also, there was no significant correlation between (a) Surgency and OD ( $r=.355, p=.235)$, (b) Surgency and

Table 2. Means (M) and standard deviations (SD) for emotional processes scores for each group

\begin{tabular}{lcccc}
\hline Emotional processes & Group & $\mathrm{M}(\mathrm{SD})$ & $t$ & Cohen's d \\
\hline Surgency & CWS & $4.28(.68)$ & .340 & .14 \\
& CWNS & $4.18(.72)$ & & \\
Negative affectivity & CWS & $4.24(.78)$ & 1.636 & .65 \\
& CWNS & $3.74(.75)$ & & \\
Effortful control & CWS & $5.42(.40)$ & -1.436 & -.57 \\
& CWNS & $5.68(.51)$ & & \\
\hline
\end{tabular}

Values are presented as mean (standard deviation, SD).

CWS = children who stutter; CWNS= children who do not stutter.

Table 3. Correlation between emotional processes and the rates of other disfluencies (OD), stuttering-like disfluencies (SLD) for children who stutter (CWS) group

\begin{tabular}{lccccc}
\hline & Surgency & $\begin{array}{c}\text { Negative } \\
\text { affectivity }\end{array}$ & $\begin{array}{c}\text { Effortful } \\
\text { control }\end{array}$ & OD & SLD \\
\hline Surgency & & & & & \\
Negative affectivity & -.168 & & & & \\
Effortful control & -.211 & .084 & & \\
OD & .042 & -.545 & -.004 & & \\
SLD & .074 & .007 & .182 & .000 & \\
\hline
\end{tabular}

$\operatorname{SLD}(r=.366, p=.219)$, (c) Negative Affectivity and OD $(r=.602$, $p=.029),(\mathrm{d})$ Negative Affectivity and SLD $(r=-.232, p=.446)$, (e) Effortful Control and OD $(r=.500, p=.082)$, and (f) Effortful Control and SLD $(r=-.127, p=.679)$ within CWNS (Tables 3 and 4).

\section{Stuttering Rates under Emotional Stressor Conditions within Each Group}

Descriptive information on OD and SLD observed under the four emotional stressor conditions for CWS and CWNS is shown in Table 5. The findings indicate that there was a significant interaction between the talker group (i.e., CWS vs. CWNS) and the emotional stressor conditions on SLD rates $\left(F_{(2.278,52.39)}=5.199\right.$, $p=0.007$; Figure 1). Specifically, there was a significant difference in the rates of SLD during the narratives under the four emotional stressor conditions for CWS $\left(F_{(3,33)}=5.997, p=.002\right)$. The results of the Bonferroni post-hoc test indicated that the emotional stressor "Frustration" $(\mathrm{M}=6.88, \mathrm{SD}=5.98)$ showed a higher rate of SLD than "Neutral" $(\mathrm{M}=4.55, \mathrm{SD}=5.49 ; p=.006)$. Conversely, there was no significant difference in the SLD rates during the narra-

Table 4. Correlation between emotional processes and the rates of other disfluencies (OD), stuttering-like disfluencies (SLD) for children who do not stutter (CWNS) group

\begin{tabular}{lccccc}
\hline & Surgency & $\begin{array}{c}\text { Negative } \\
\text { affectivity }\end{array}$ & $\begin{array}{c}\text { Effortful } \\
\text { control }\end{array}$ & OD & SLD \\
\hline Surgency & & & & & \\
Negative affectivity & -.036 & & & \\
Effortful control & -.054 & .058 & & \\
OD & .355 & .602 & .500 & \\
SLD & .366 & -.232 & -.127 & -.451 \\
\hline
\end{tabular}

Table 5. Means and standard deviations of the rates of other disfluencies (OD), stuttering-like disfluencies (SLD) under emotional stressor conditions in each group

\begin{tabular}{lccc}
\hline Group & Emotional stressor & OD & SLD \\
\hline CWS & Neutral & $1.54(1.15)$ & $4.55(5.49)$ \\
& Anxiety & $1.61(1.15)$ & $5.73(5.76)$ \\
& Pleasure & $1.92(1.33)$ & $5.73(6.30)$ \\
& Frustration & $1.85(1.08)$ & $6.88(5.98)$ \\
CWNS & Neutral & $2.14(1.31)$ & $.47(.39)$ \\
& Anxiety & $2.49(1.63)$ & $.69(.47)$ \\
& Pleasure & $2.77(1.28)$ & $.67(.27)$ \\
& Frustration & $3.35(1.75)$ & $.64(.63)$ \\
\hline
\end{tabular}

Values are presented as mean (standard deviation, SD).

CWS = children who stutter; CWNS = children who do not stutter. 


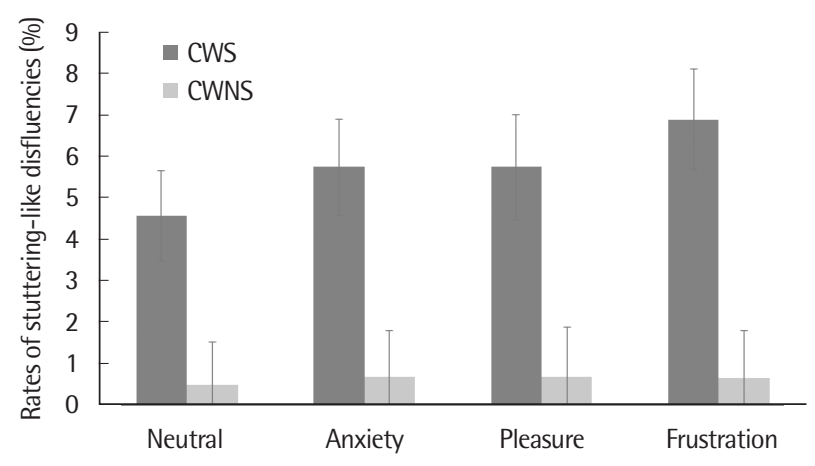

Figure 1. The rates of stuttering-like disfluencies (SLD) for each group under the four emotional stressor conditions. Error bars represent standard error of the mean. CWS = children who stutter; CWNS = children who do not stutter.

tives under the four emotional stressors for CWNS $\left(F_{(3,36)}=\right.$ $1.026, p=.393)$.

On the other hand, there was no significant interaction between the talker group (i.e., CWS vs. CWNS) and the emotional stressor conditions on OD rates $\left(F_{(3,69)}=.963, p=.415\right.$; Figure 2$)$. Specifically, there was no significant difference in the rates of OD during the narratives under the four emotional stressor conditions for CWS $\left(F_{(3,33)}=.454, p=.716\right)$ and CWNS $\left(F_{(3,36)}=3.537, p=.024\right.$, Bonferronicorrected $p>.025)$.

\section{DISCUSSION \& CONCLUSION}

The present study resulted in three main findings. The first main finding indicated no significant differences in emotional reactivity and regulation between CWS and CWNS. The second main finding indicated no significant correlations between CWS's emotional reactivity/regulation and disfluencies. The third main finding indicated that there was a significant interaction effect between the talker group (i.e., CWS vs. CWNS) and the emotional stressor conditions on SLD rates. Specifically, CWS showed higher rates of SLD under the "Frustration" condition compared with the "Neutral" condition, whereas CWNS showed no significant differences in SLD rates among the emotional stressor conditions.

The general implications of each of these findings are discussed below.

\section{Group Comparisons of Emotional Reactivity and Regulation}

The findings indicated no significant differences in emotional

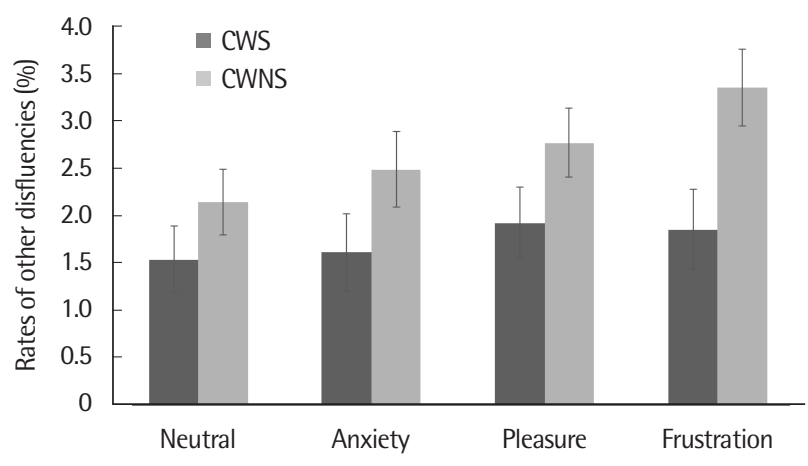

Figure 2. The rates of other disfluencies (OD) for each group under the four emotional stressor conditions. Error bars represent standard error of the mean. CWS = children who stutter; CWNS = children who do not stutter.

reactivity and regulation between CWS and CWNS. Although the present finding is consistent with the results of some studies that reported no significant differences in Surgency between CWS and CWNS (Cha, 2015; Eggers et al., 2010; Park, 2015), it is inconsistent with most previous studies that reported differences in emotional processes between CWS and CWNS (Anderson et al., 2003; Eggers, de Nil, \& van den Bergh, 2009; Felsenfeld, van Beijsterveldt, \& Boomsma, 2010; Karrass et al., 2006). Based on these findings, it can be cautiously suggested that there is no difference in temperamental characteristics such as emotional reactivity and regulation between CWS and CWNS. Of course, our results do not preclude the possibility that our relatively small sample size may have contributed to the null finding. Interestingly, when examining the descriptive information and the effect sizes, CWS scored higher in Negative Affectivity and lower in Effortful Control than CWNS with medium effects (Cohen, 1992). Therefore, further research is needed to determine if there are differences in emotional reactivity and regulation between CWS and CWNS with a larger sample size.

In general, this finding seems different from what people perceive about the temperament of stuttering children. Research has shown that many people perceive stuttering children as shy and self-conscious (Craig, Tran, \& Craig, 2003). Similarly, the mothers of the stuttering children described their children as sensitive, anxious, and fearful (Fowlie \& Cooper, 1978). However, the results of this study do not seem to support the perception of the general public toward children who stutter. 


\section{Relationship between Emotional Reactivity/regulation and Disfluencies Rates within Each Group}

The findings indicated no significant correlations between disfluency rates and emotional reactivity/regulation in CWS and CWNS. This is consistent with the results of a previous study (Choi et al., 2016) that reported that there was no relationship between Negative Affectivity and stuttering frequency for CWS, but inconsistent with Choi et al's finding that reported a significant correlation between Surgency and stuttering frequency for CWS.

Such null findings could mean that there are actually no correlations between the rates of disfluency and emotional temperaments. On the other hand, there is also a possibility that the correlation was not discovered due to the small sample size. Another alternative and interesting possibility is that the null finding may result from an interaction between emotional reactivity and regulation. Emotional reactivity and regulation are two different temperamental characteristics that act independently from each other (Arnold et al., 2011; Walden et al., 2012; Ntourou et al., 2013).

Thus, it can be speculated that some CWS with high emotional reactivity may have high emotion regulation as reported in Jones et al. (2014) - such that they put a brake on their emotional responses - which would result in a lower impact of emotional reactivity on stuttering. To determine how emotional reactivity and regulation interact with each other to jointly affect stuttering, future research needs to employ psychophysiological methods (e.g., electrodermal activity or respiratory sinus arrhythmia) to assess children's emotional reactivity and regulation.

\section{Stuttering Rates under Emotional Stressor Conditions}

Lastly, the findings indicated that there was a significant difference in the rates of SLD between the "Frustration" and "Neutral" conditions in CWS, but not in CWNS. Specifically, CWS stuttered more in during the "Frustration" condition than the "Neutral" condition. Conversely, there were no significant differences in the rates of SLD between the "Anxiety" and the "Neural" as well as the "Pleasure" and the "Neural" conditions in both CWS and CWNS. This finding suggests that a frustrating situation may serve as an emotional stressor that triggers an increase in CWS's stuttering. According to Guitar (2019), two possible explanations are possible for this finding. First, when an individual experiences frustration, a behavioral inhibition system in the brain is activated which increases CWS's freezing, flight and avoidance behaviors. These behaviors are expressed as core and secondary behaviors. Second, negative emotions such as frustration tend to dominate the neural resources in the right hemisphere which people who stutter may use to compensate for deficits in the left hemisphere regions for speech production, resulting in disrupted speech fluency. Further research with increased power is needed to support or refute the finding.

On the other hand, the nonsignificant findings for the "Pleasure" and "Anxiety" conditions were not expected. It is possible that the conditions we created did not elicit the intended emotions strongly enough to increase stuttering. Indeed, the results of the manipulation check indicated that children reported they experienced frustrations during the "Frustration" condition to a greater degree than anxiety during the "Anxiety" condition. Regarding the "Pleasure" condition, although the condition seemed to elicit our intended emotion from the child, it is possible that children may not have felt much excitement when they received our gift because it may not have been what they wanted to receive.

In general, previous research has shown that CWS showed more frustration in a disappointed situation than CWNS, suggesting that CWS are more emotionally vulnerable to frustrating situations than CWNS (Jones et al., 2014; Ntourou et al., 2013; Walden et al., 2012). The present finding went one step further to suggest that CWS's negative emotional reactivity as activated by the frustrating situation may lead to increased stuttering. Therefore, although further studies with a larger sample size are needed, we cautiously conclude that CWS's fluency may be disrupted by negative emotions such as frustration elicited by an external stressor.

\section{LIMITATION}

There are several limitations to this study. First, the limited number of participants contributed to low power, which increased the possibility of incorrectly retaining a null hypothesis or finding significance when, in fact, there may be a significant or nonsignificant difference or relationship respectively. Therefore, future studies should be conducted with larger numbers of participants to detect a real difference or association. Second, this study examined 
children's emotional reactivity and regulation based on parental reports; this has the great advantage of observing children's various behaviors over a long period of time but has a limitation in that their rating may be subjective. In addition, emotions have relatively fluctuating characteristics, so a more accurate analysis will be possible if the methods of behavioral observation and psychophysiology are used in conjunction with parental reports.

\section{REFERENCES}

Ahadi, S. A., \& Rothbart, M. K. (1994). Temperament, development, and the Big Five. In C. F. Halverson, Jr., G. A. Kohnstamm, \& R. P. Martin (Eds.), The developing structure of temperament and personality from infancy to adulthood (pp. 189-207). Hillsdale, NJ: Erlbaum.

Alm, P. A. (2014). Stuttering in relation to anxiety, temperament, and personality: Review and analysis with focus on causality. Journal of Fluency Disorders, 40, 5-21.

Ambrose, N. G., \& Yairi, E. (1999). Normative disfluency data for early childhood stuttering. Journal of Speech, Language, and Hearing Research, 42(4), 895-909.

Anderson, J. D., Pellowski, M. W., Conture, E. G., \& Kelly, E. M. (2003). Temperamental characteristics of young children who stutter. Journal of Speech, Language, and Hearing Research, 46(5), 1221-33.

Arnold, H. S., Conture, E. G., Key, A. P., \& Walden, T. (2011). Emotional reactivity, regulation and childhood stuttering: a behavioral and electrophysiological study. Journal of Communication Disorders, 44(3), 276-293.

Bloodstein, O. (1995). A handbook on stuttering (5th ed.). San Diego, CA: Singular Press.

Bloodstein, O., \& Bernstein-Ratner, N. (2008). A handbook on stuttering (6th ed.), New York, NY: Thomson-Delmar.

Cha, H. (2015). Characteristics of temperament and communication attitudes in school-age children who stutter (Master's thesis). Chosun University, Gwangju, Korea.

Choi, D., Conture, E. G., Walden, T. A., Jones, R. M., \& Kim, H. (2016). Emotional diathesis, emotional stress, and childhood stuttering. Journal of Speech, Language, and Hearing Research, 59(4), 616-630.

Choi, D., Conture, E. G., Walden, T. A., Lambert, W. E., \& Tumanova, V. (2013). Behavioral inhibition and childhood stuttering. Journal of Fluency Disorders, 38(2), 171-183.

Cohen, J. (1992). A power primer. Psychological Bulletin, 112(1), 155-159.
Conture, E. G., Kelly, E. M., \& Walden, T. A. (2013). Temperament, speech and language: an overview. Journal of Communication Disorders, 46(2), 125-142.

Conture, E. G., \& Walden, T. (2012). Dual diathesis-stressor model of stuttering. In L. Bellakova \& Y. Filatova (Eds.), Theoretical issues of fluency disorders (pp. 94-127). Moscow, Russia: National Book Centre.

Conture, E. G., Walden, T. A., Arnold, H. S., Graham, C. G., Hartfield, K. N., \& Karrass, J. (2006). Communication emotional model of stuttering. In N. R. Bernstein (Ed.), Stuttering: new research directions (pp. 17-46). Mahwah, NJ: Erlbaum.

Craig, A., Tran, Y., \& Craig, M. (2003). Stereotypes towards stuttering for those who have never had direct contact with people who stutter: a randomized and stratified study. Perceptual and Motor Skills, 97(1), 235-245.

Eggers, K., de Nil, L. F., \& van den Bergh, B. R. (2009). Factorial temperament structure in stuttering, voice-disordered, and typically developing children. Journal of Speech, Language, and Hearing Research, 52(6), 16101622.

Eggers, K., de Nil, L. F., \& van den Bergh, B. R. (2010). Temperament dimensions in stuttering and typically developing children. Journal of Fluency Disorders, 35(4), 355-372.

Erdemir, A., Walden, T. A., Jefferson, C. M., Choi, D., \& Jones, R. M. (2018). The effect of emotion on articulation rate in persistence and recovery of childhood stuttering. Journal of Fluency Disorders, 56, 1-17.

Felsenfeld, S., van Beijsterveldt, C. E. M., \& Boomsma, D. I. (2010). Attentional regulation in young twins with probable stuttering, high nonfluency, and typical fluency. Journal of Speech, Language, and Hearing Research, 53(5), 1147-1166.

Fowlie, G. M., \& Cooper, E. B. (1978). Traits attributed to stuttering and nonstuttering children by their mothers. Journal of Fluency Disorders, 3(4), 233-246.

Gray, J. A. (1987). The psychology of fear and stress (Vol. 5). CUP Archive, Cambridge.

Guitar, B. (2019). Stuttering: an integrated approach to its nature and treatment (5th ed.). Philadelphia, PA: Wolters Kluwer.

Howell, P., Davis, S., Patel, H., Cuniffe, P., Downing-Wilson, D., Au-Yeung, J., \& Williams, R. (2004). Fluency development and temperament in fluent children and children who stutter. In A. Packman, A. Meltzer, \& H. F. M. Peters (Eds.), Theory, research and therapy in fluency disorders. Proceedings of the 4th World Congress on fluency disorders (pp. 250-256). Nijmegen, the Netherlands: University of Nijmegen Press. 
Iverach, L., Menzies, R. G., O’Brian, S., Packman, A., \& Onslow, M. (2011). Anxiety and stuttering: continuing to explore a complex relationship. American Journal of Speech-Language Pathology, 20(3), 221-232.

Johnson, K. N., Walden, T. A., Conture, E. G., \& Karrass, J. (2010). Spontaneous regulation of emotions in preschool children who stutter: preliminary findings. Journal of Speech, Language, and Hearing Research, 53(6), 14781495.

Jones, R. M., Conture, E. G., \& Walden, T. A. (2014). Emotional reactivity and regulation associated with fluent and stuttered utterances of preschool-age children who stutter. Journal of Communication Disorders, 48 , $38-51$.

Karrass, J., Walden, T. A., Conture, E. G., Graham, C. G., Arnold, H. S., Hartfield, K. N., \& Schwenk, K. A. (2006). Relation of emotional reactivity and regulation to childhood stuttering. Journal of Communication Disorders, 39(6), 402-423.

Kefalianos, E., Onslow, M., Block, S., Menzies, R., \& Reilly, S. (2012). Early stuttering, temperament and anxiety: two hypotheses. Journal of Fluency Disorders, 37(3), 151-163.

Kim, Y. T., Hong, G. H., Kim, K. H., Jang, H. S., \& Lee, J. Y. (2009). Receptive \& Expressive Vocabulary Test (REVT). Seoul: Seoul Community Rehabilitation Center.

Lee, K. O. (2004). Validation study for CBQ scale with Korean children. Journal of Early Childhood Education, 24(5), 101-120.

Lewis, K. E., \& Golberg, L. L. (1997). Measurements of temperament in the identification of children who stutter. European Journal of Disorders of Communication, 32(4), 441-448.

Lim, J. Y., \& Bae, Y. J. (2015). Validation study of Korean version of the Rothbart's children's behavior questionnaire. Korean Journal of Human Ecology, 24(4), 477-497.

Mayer, M. (1967). A Boy, a Dog and a Frog. New York: Dial Books for Young Readers.

Mayer, M. (1969). Frog, Where Are You. New York: Dial Books for Young Readers.

Mayer, M. (1971). A Boy, a Dog and a Frog and a Friend. New York: Dial Books for Young Readers.

Mayer, M. (1974). Frog Goes to Dinner. New York: Dial Books for Young Readers.

Mayer, M. (1975). One Frog Too Many. New York: Dial Books for Young Readers.

Mcdevitt, S. C., \& Carey, W. B. (1978). The measurement of temperament in
3-7 year old children. Journal of Child Psychology and Psychiatry, 19(3), 245-253.

Ntourou, K., Conture, E. G., \& Walden, T. A. (2013). Emotional reactivity and regulation in preschool-age children who stutter. Journal of Fluency Disorders, 38(3), 260-274.

Park, Y. S. (2015). Temperamental characteristics of preschool children who do and do not stutter (Master's thesis). Ewha Womans University, Seoul, Korea.

Putnam, S. P., \& Rothbart, M. K. (2006). Development of short and very short forms of the Children's Behavior Questionnaire. Journal of Personality Assessment, 87(1), 102-112.

Rothbart, M. K., Ahadi, S. A., Hershey, K. L., \& Fisher, P. (2001). Investigations of temperament at three to seven years: the Children's Behavior Questionnaire. Child Development, 72(5), 1394-1408.

Rothbart, M. K., \& Bates, J. E. (2006). Temperament. In Damon, W., Lerner, R. M., \& Eisenberg, N. (Eds.), Handbook of child psychology, social emotional, and personality development (pp.99-166). New-York: Wiley.

Schwenk, K. A., Conture, E. G., \& Walden, T. A. (2007). Reaction to background stimulation of preschool children who do and do not stutter. Journal of Communication Disorders, 40(2), 129-141.

Sim, H. S., Shin, M. J., \& Lee, E. J. (2010). Paradise-Fluency Assessment II. Seoul: Paradise Welfare Foundation.

Smith, A., \& Weber, C. (2017). How stuttering develops: the multifactorial dynamic pathways theory. Journal of Speech, Language, and Hearing Research, 60(9), 2483-2505.

Spinrad, T. L., Eisenberg, N., Harris, E., Hanish, L., Fabes, R. A., Kupanoff, K., ... \& Holmes, J. (2004). The relation of children's everyday nonsocial peer play behavior to their emotionality, regulation, and social functioning. Developmental Psychology, 40(1), 67-80.

Thompson, R. A. (1994). Emotion regulation: a theme in search of definition. Monographs of the Society for Research in Child Development, 59(23), 25-52.

Walden, T. A., Frankel, C. B., Buhr, A. P., Johnson, K. N., Conture, E. G., \& Karrass, J. M. (2012). Dual diathesis-stressor model of emotional and linguistic contributions to developmental stuttering. Journal of Abnormal Child Psychology, 40(4), 633-644.

Zalewski, M., Lengua, L. J., Wilson, A. C., Trancik, A., \& Bazinet, A. (2011). Emotion regulation profiles, temperament, and adjustment problems in preadolescents. Child Development, 82(3), 951-966. 
Appendix 1. CWS participant's age, grade, vocabulary, stuttering severity and period

\begin{tabular}{|c|c|c|c|c|c|c|c|}
\hline CWS & Gender & Age & Grade & Receptive vocabulary & Expressive vocabulary & Stuttering severity & Period of therapy \\
\hline 1 & M & $7 ; 9$ & 1 & 80-90\%ile & $60-70 \%$ ile & Mild & More than 1 year \\
\hline 2 & M & $8 ; 10$ & 3 & 100\%ile & 100\%ile & Mild & More than 1 year \\
\hline 3 & M & $7 ; 11$ & 1 & 80-90\%ile & 60-70\%ile & Moderate & More than 1 year \\
\hline 4 & M & $8 ; 2$ & 3 & 90\%ile & 70\%ile & Mild & More than 1 year \\
\hline 5 & M & $6 ; 3$ & 1 & 50\%ile & 90-100\%ile & Severe & Less than 6 months \\
\hline 6 & M & $8 ; 11$ & 3 & 100\%ile & 100\%ile & Mild & Less than 6 months \\
\hline 7 & M & $6 ; 7$ & 1 & 90-100\%ile & 100\% ile & Moderate & Less than 6 months \\
\hline 8 & $M$ & $6 ; 10$ & 1 & $30 \%$ ile & 80-90\%ile & Mild & Less than 6 months \\
\hline 9 & M & $6 ; 1$ & 1 & 90-100\%ile & 80-90\%ile & Moderate & Less than 6 months \\
\hline 10 & M & $7 ; 6$ & 2 & 90-100\%ile & 80-90\%ile & Severe & Less than 6 months \\
\hline 11 & M & $7 ; 11$ & 2 & 90-100\%ile & 80-90\%ile & Severe & Less than 6 months \\
\hline 12 & $M$ & $8 ; 7$ & 3 & 100\%ile & 100\%ile & Moderate & Less than 6 months \\
\hline
\end{tabular}

CWS = children who stutter; $M=$ male; $F=$ female.

Appendix 2. CWNS participant's age, grade, vocabulary

\begin{tabular}{cccccc}
\hline CWNS & Gender & Age & Grade & $\begin{array}{c}\text { Receptive } \\
\text { vocabulary }\end{array}$ & $\begin{array}{c}\text { Expressive } \\
\text { vocabulary }\end{array}$ \\
\hline 1 & M & $7 ; 9$ & 2 & $90 \%$ ile & $80 \%$ ile \\
2 & M & $7 ; 5$ & 1 & $50 \%$ ile & $90-100 \%$ ile \\
3 & F & $8 ; 1$ & 2 & $10-20 \%$ ile & $60-70 \%$ ile \\
4 & F & $8 ; 11$ & 3 & $100 \%$ ile & $90-100 \%$ ile \\
5 & M & $8 ; 10$ & 3 & $70-80 \%$ ile & $90 \%$ ile \\
6 & F & $7 ; 5$ & 1 & $10 \%$ ile & $70 \%$ ile \\
7 & F & $8 ; 10$ & 3 & $70-80 \%$ ile & $60-70 \%$ ile \\
8 & F & $8 ; 3$ & 2 & $80-90 \%$ ile & $90-100 \%$ ile \\
9 & F & $8 ; 3$ & 2 & $10-20 \%$ ile & $60-70 \%$ ile \\
10 & $F$ & $8 ; 3$ & 2 & $90-100 \%$ ile & $90-100 \%$ ile \\
11 & $F$ & $7 ; 1$ & 1 & $10 \%$ ile & $80 \%$ ile \\
12 & $F$ & $7 ; 11$ & 2 & $60 \%$ ile & $20-30 \%$ ile \\
13 & M & $8 ; 9$ & 2 & $100 \%$ ile & $90 \%$ ile \\
\hline
\end{tabular}

CWNS = children who do not stutter; $M=$ male; $F=$ female. 


\section{국문초록}

\section{저학년 학령기 말더듬 아동과 일반 아동의 정서처리에 따른 비유창성 연구}

\section{김혜원 + 최다혜 ${ }^{2}$ 심현섭}

${ }^{1}$ 이화여자대학교 대학원 언어병리학과, ${ }^{2}$ University of South Alabama

배경 및 목적: 본 연구는 저학년 학령기 말더듬 아동과 일반 아동 집단 간 정서처리(emotional reactivity와 emotional regulation)의 차 이에 대해 살펴보았다. 또한, 긍정적 또는 부정적 정서를 일으키는 요인에 따라 비유창성이 증가되는지 알아보고자 하였다. 방법: 이 연 구에 참여한 대상자는 초등학교 저학년(1-3학년) 말더듬 아동 12 명, 일반 아동 13 명이었다. 정서처리 특성을 평가하기 위해 한국어 버전 $\mathrm{CBQ}$-간편형 척도를 사용하였다. $\mathrm{CBQ}$-간편형 척도는 정서처리를 세 가지 상위요인(외향성, 부정적 정서, 의도적 통제)로 나누어 검사 하였다. 대상자들은 정서 스트레스 요인(중립, 긴장, 기쁨, 좌절) 과제 후에 글자 없는 그림책으로 이야기를 산출하였다. 결과: (1) 말더듬 아동과 일반 아동 간 세 가지 상위요인(외향성, 부정적 정서, 의도적 통제)에서 유의미한 차이가 나타나지 않았다. (2) 말더듬 아동과 일 반 아동은 정서처리의 세 가지 상위요인과 비유창성 비율(SLD, OD)에서 유의미한 상관관계가 나타나지 않았다. (3) '좌절'과 ‘중립' 상 황 간 말더듬 아동은 SLD 비율에 유의미한 차이가 나타났으나, 일반 아동은 차이가 없었다. 논의 및 결론: 본 연구의 결과, 말더듬 아동 은 정서처리에 있어서 일반 아동과 다른 차이가 없었으나, 말더듬 아동의 말산출체계가 좌절 상황에서 취약하다는 것을 확인할 수 있었 다. 또한, 말더듬 아동의 유창성은 좌절되는 감정으로 인해 방해받을 가능성이 높다는 것을 보여준다.

핵심어: 저학년 초등학생 아동, 정서처리, 정서 스트레스 요인, 비유창성, 말더듬

\section{참고문헌}

김영태, 홍경훈, 김경희, 장혜성, 이주연 (2009). 수용·표현 어휘력 검사(REVT). 서울: 서울장애인종합복지관. 박영선 (2015). 학령전기 말더듬 아동과 일반 아동의 기질 특성 비교. 이화여자대학교 대학원 석사학위논문.

심현섭, 신문자, 이은주 (2010). 파라다이스-유창성검사 II (P-FA-II). 서울: 파라다이스 복지재단. 이경옥 (2004). 유아 기질 척도 (CBQ)의 타당화를 위한 기초 연구. 유아교육연구, 24(5), 101-120. 임지영, 배윤진 (2015). 한국판 Rothbart 유아용 기질 척도(Children's Behavior Questionnaire)의 타당화. 한국생활과학회, 24(4), 477-497. 차현 (2015). 학령기 말더듬 아동과 일반 아동의 기질과 의사소통태도 특성. 조선대학교 석사학위논문.

\section{ORCID}

